\title{
THE 'ULTRACHARISMATICS' OF CORINTH AND THE PENTECOSTALS OF LATIN AMERICA AS THE RELIGION OF THE DISAFFECTED
}

\author{
Gary S. Shogren
}

\begin{abstract}
Summary
This paper arises from research on 1 Corinthians within a Latin American milieu. It shows the value of studying God's word from nonfirst world perspectives, particularly with regard to the themes of societal status and the charismata in the first century church. The majority opinion is that 1 Corinthians was written to correct a 'pneumatic enthusiasm', with such diverse components as the denial of the resurrection, egalitarianism and triumphalism. It would follow that the teaching about the charismata in chapters 12-14 is directed against that same outlook. We will argue that the majority of the letter is addressed to Christians who dabbled in philosophy as a sign of their upward mobility. But then, using sociological insights from Roman Corinth and from the contemporary Latin American church, we will propose that chapters 12-14 speak to the marginalised of the church. They had turned to the showier charismata as a means of creating an identity for themselves in a church where the elitists received all the attention ... as well as invitations to the table of other rich Christians. Thus while the bulk of the letter is a harsh rebuke to the arrogant elitists, chapters 12-14 are directed to the marginalised ultracharismatics, showing them that all of God's gifts must be used in the loving service of the body.
\end{abstract}

https://tyndalebulletin.org/

https://doi.org/10.53751/001c.29185 


\section{Introduction: 1 Corinthians 12-14 in the Scope of the Letter}

In 12:1 Paul responds to a written question regarding the gifts of the Spirit. ${ }^{1}$ The main issue was that some were ignoring apostolic custom, which the apostle reaffirms in chapter 14. For want of a better label, we will refer to them as 'ultracharismatics'. Given Paul's response, we will argue further down that tongues were causing some - whether it was their intention or no - to withdraw inwardly from the group dynamic of the assembly. What is more readily obvious from the text is that their noise and unintelligibility tended to overwhelm those who wanted to unite the group with teaching, song, or prophetic revelation (14:26). John Hurd is not quite on the mark, therefore, that chapters 12-14 are 'one long attack upon the notion that speaking in tongues was the single or the best manifestation of the Spirit at work in the Church'. ${ }^{2}$ This may have been the specific issue in the letter from Corinth, but Paul's larger criticism has to do with using any charism without due care to the church's need for corporate edification.

Much confusion has been caused at this juncture by the introduction of the word 'ecstatic', a term of slippery definition. Nothing in chapter 14 necessarily demands the experience of higher consciousness. Nor do we see evidence that the Corinthians were taking their cue from the frenzied behaviour of pagan prophecy. ${ }^{3}$

1 The referent of pneumatikon, if taken as the neuter gender, as in the NRSV, most English, German, French and Spanish versions, most commentaries. The neuter is indicated by the parallel in 1 Cor. 14:1.

2 John C. Hurd, Jr., The Origin of 1 Corinthians (2nd edn.; Macon, GA: Mercer, 1983): 192. Hurd correctly rejects (186-87) that the church had asked about the discernment of spiritual manifestations, as thinks Chrysostom, Hom. 1 Cor. 29.1-3; also Wolfgang Schrage, Der erste Brief an die Korinther (EKKNT 7/3; NeukirchenVluyn: Neukirchener, 1991-2001): 3.117-26.

3 See the full and convincing treatment by Christopher Forbes, Prophecy and Inspired Speech in Early Christianity and its Hellenistic Environment (Peabody, MA: Hendrickson, 1997). For a different view see Luke Timothy Johnson, 'Tongues, Gift of' in Anchor Bible Dictionary (New York: Doubleday, 1992): 6.596-600. As an example of the modern confusing of prophecy, glossolalia and ecstatic speech, see Richard A. Horsley, 'Spiritual Elitism in Corinth', NovT 20 (1978): 203-231. On p. 228 he sets out to prove that 'prophetic ecstasy is a climactic experience, perhaps the highest spiritual experience in Philo's religion'. To be sure, in Heir. 264-65, Philo does represent Abraham as being in a trance in Gen. 15:12: '[A] trance, which proceeds from inspiration, takes violent hold of us, and madness seizes upon us, for when the divine light sets this other rises and shines, and this very frequently happens to the race of prophets' (Yonge version). But in the literary and religious context this has nothing to do with glossolalia, as Horsley would wish. 
Glossolalia in Corinth dated rather from the founding of the church, Paul himself being an energetic practitioner of that charism (14:18). But what was the source of this new ultracharismatic wave that arose in the three or so years since his first work in that city, and how did that relate to the other Corinthian failings? And how do chapters 12-14 fit in with the rest of Paul's letter?

\subsection{Was one of the parties of 1 Corinthians 1:12 ultracharismatic?}

It would be neatest to hypothesise a single cause for all the Corinthian problems if that were deemed feasible. In that case, the ultracharismatics would be a manifestation of a root theological aberration.

One approach is to see them as a theological party. A century and a half ago, F. C. Baur's 'Tübingen theory' or Tendenz criticism saw in the four names of 1:12 a proof of his understanding of the epistle and indeed of all of early Christianity. ${ }^{4}$ He used Hegelian philosophy to pit the reactionary judaizing devotees of Peter against the forward-looking universalistic adherents of Paul. That is, the historical struggle of thesis and antithesis in Corinth and elsewhere was consciously doctrinal. Since Baur there have been plenty of theories, although typically with a rejection of his Hegelian grid, as to what doctrine these two, three or four theological groups promoted and which might have been the party of the ultracharismatics. ${ }^{5}$

Another view, one that sometimes bleeds into today's majority view (see below) is that Corinth was infected with a single competitor to the Pauline gospel, the Tendenz of Gnosticism. ${ }^{6}$ This assumes that Gnosticism was, at least in seed form, contemporary with nascent Christianity, not just a later heresy. Hence, the Corinthians rejected the bodily resurrection of the saints and were devoted seekers after gnōsis

4 See Stephen Neill and N. T. Wright, The Interpretation of the New Testament, 1861-1986 (2nd edn; OUP, 1988): 23-30.

5 See the attempts of Archibald Robertson and Alfred Plummer, First Epistle of St. Paul to the Corinthians (ICC; 2nd edn; Edinburgh: T\&T Clark, 1914): 11-13; Otto Kuss, Die Briefe an die Römer, Korinther und Galater (RNT; Regensburg: Pustet, 1940): 114, 120-21; T. W. Manson in M. Black, ed., 'The Corinthian correspondence (I) [1941]' in Studies in the Gospels and Epistles (Manchester: Manchester University, 1962): 190-209; C. K. Barrett, 'Christianity at Corinth [1964]' in Essays on Paul (Philadelphia, PA: Westminster, 1982): 1-27 at defining precisely the penchants of each of the four groups. We applaud that recent studies have tended to be wary of over-confident reconstructions of history, especially in cases like this, where the evidence is slim or nonexistent.

6 Walter Schmithals, Gnosticism in Corinth: an investigation of the letters to the Corinthians, tr. J. E. Steely (Nashville, TN: Abingdon, 1971). 
(see $1: 5 ; 8: 1 ; 13: 8$ ). Walter Schmithals has been the key proponent of this viewpoint, but his attempt to correlate a Corinthian heresy with what is known of Gnosticism raises serious methodological questions about the existence of Gnosticism in the first century and about evidence from the epistle that does not fit a Gnostic model. ${ }^{7}$ This is why some today prefer to link this gnōsis with a mystical wisdom tradition derived from Judaism. ${ }^{8}$

\subsection{Was ultracharismaticism related to realised eschatology?}

That this is now the conventional explanation is indicated when Jerome Neyrey could make the offhanded comment - 'As everyone knows, some members of the Corinthian church claimed to share already in the power of Jesus' resurrection.' 9 These analyses discern in Corinth a wave of 'charismatic enthusiasm', 'over-realised eschatology' or 'pneumaticism'. ${ }^{10}$ Gordon Fee gives a clear example:

- To begin, 'the key issue between [Paul and the Corinthians] is a basic theological problem, what it means to be pneumatikos'. (10)

- Thus the Corinthians claim that we reign as kings now; we should not suffer now: 'Paul sees their present boasting [in 4:8] as

7 See for example the response by R. McLachlan Wilson, 'How Gnostic were the Corinthians?' NTS 19 (1972-73): 65-74.

8 E.g. Birger Pearson, 'Hellenistic Jewish Wisdom Speculation and Paul' in R. L. Wilken, ed., Aspects of Wisdom in Judaism and Early Christianity (Notre Dame: Notre Dame University, 1975): 43-66.

9 Jerome H. Neyrey, Paul, in Other Words: A Cultural Reading of his Letters (Louisville, KY: Westminster John Knox, 1990): 34. Note especially the major new commentaries by Wolfgang Schrage; Anthony C. Thiselton, The First Epistle to the Corinthians (NIGNT; Grand Rapids, MI: Eerdmans, 2000); Thiselton's seminal article, 'Realized eschatology at Corinth', NTS 24 (1978): 510-26. See also Gordon D. Fee, The First Epistle to the Corinthians (NICNT; Grand Rapids, MI: Eerdmans, 1987); Hans Conzelmann, 1 Corinthians, tr. James W. Leitch (Hermeneia; Philadelphia, PA: Fortress, 1975): 14-16; D. A. Carson, Showing the Spirit: a theological exposition of 1 Corinthians 12-14 (Grand Rapids, MI: Baker, 1987): 16-17.

10 There is a confusion of tongues concerning these labels. Some proponents of the 'enthusiasm' view perceive it as a rejection of Schmithals' Gnostic theory; others understand it to be the same theory; others still a modification of it. An important parallel between Gnostic, 'pneumatic', 'charismatic' or whatever models is that they tend to emphasize the same data and interpret those data in similar directions: for example, that 'you reign already' in 1 Cor. $4: 8$ is a theological-eschatological statement and not primarily sociological or attitudinal. We think that the "charismatic enthusiasm' proponents should go back even further to examine what lies behind the exegetical conclusions of the 'Gnostic' school and see whether there are not better explanations of the specific texts. 
tantamount to their supposing the final reign of God already to have begun'. (173)

- Holiness has to do with the inner person, not with the physical body: the Corinthians excused their visits to prostitutes because they "looked for a "spiritual" salvation that would finally be divested of the body'. (257)

- Marriage is an anachronism: 'they are above the merely earthly existence of others; marriage belongs to this age that is passing away'. (269)

- Gender distinctions no longer apply; women should put aside the veil: 'their spiritualised eschatology also involved some kind of breakdown in the distinction between the sexes'. (498)

- They claim to speak in the tongues of angels with a full eschatological endowment of the Spirit: 'they believed that they had already entered into some expression of angelic existence'. (631)

- There is no (future) resurrection, but the resurrection is spiritual or is realised eschatology: 'In their view, by the reception of the Spirit, and especially the gift of tongues, they had already entered the true "spirituality" that is to be (4:8); already they had begun a form of angelic existence ... in which the body was unnecessary and unwanted, and would finally be destroyed'. (715)

That is, the Corinthians had overblown Paul's own teaching on realised eschatology and charismatic gifts, and this explains their triumphalism and their peculiar use of glossolalia. Those who disrupted the meetings with tongues were the same individuals who gloried in their wisdom, boasted of being kings and thought themselves beyond normal sexual purity. Paul controverts them by underscoring the 'not yet' of his eschatological message (especially in $4: 8 ; 13: 8-12 ; 15: 23-28$ ).

A unified theory such as the Gnosticism and/or enthusiasm views has the attractiveness of simplicity. But this cannot in itself incite us to oversimplification or the selective use of evidence, the weakness that many see in Walter Schmithals' approach. I find even the 'pneumaticenthusiastic' theory unconvincing, no more so than when we come to chapters 12-14, where there is little evidence of doctrinal disagreement between Paul and the ultracharismatics. His objection as found in the text is social and doxological: it has to do with the practice of the charismata within worship. Thus of late there has arisen the explanation that the abuse of glossolalia is not the fruit of a different 
eschatology, but of sociological factors, especially status competition within the house churches.

\subsection{Were the factions in 1 Corinthians 1:12 part of a quest for social status?}

\section{a. The quest for status in Roman Corinth}

We are rich in new sociological insights into Roman Corinth, nourished by a century of archaeological work that has only grown more fruitful in the last few decades. ${ }^{11}$ Corinth was a city of relatively easy upward mobility. The acquisition and conspicuous display of knowledge was a powerful status indicator. If 'not many were wise' (1:26) when they were converted, this did not prevent them from social climbing through (as the apostle saw it) pseudo-intellectual show.

Amusingly, this insight corroborates an older interpretation (see John Chrysostom, the Introduction to his Hom. 1 Cor.; also 4:4): that the Corinthians had gone awry through a craving for philosophical wisdom. They sought through rationalist speculation a deeper truth than was offered in the cross, and from that a higher status. They competed in courting powerful friends by inviting them to banquets and in sponsoring popular teachers as clients. These Christians were open to the influence of prevailing philosophical trends, such as Stoicism, leading them to reject the resurrection of the saints while at the same time confessing the resurrection of Jesus. Their attraction to Apollos, Cephas and Paul (and to a Christ-party?) was based on the status their persons communicated. Paul's unease at receiving financial

11 See especially Gerd Theissen, The social setting of Pauline Christianity: essays on Corinth, tr. J. H. Schütz (Philadelphia, PA: Fortress, 1982); Andrew D. Clarke, Secular and Christian leadership in Corinth: a socio-historical and exegetical study of 1 Corinthians 1-6 (AGJU, 18; Leiden: Brill, 1993); Ben Witherington III, Conflict and community in Corinth (Grand Rapids, MI: Eerdmans, 1995); Bruce W. Winter, After Paul left Corinth: the influence of secular ethics and social change (Grand Rapids, MI: Eerdmans, 2001); the commentaries by Anthony C. Thiselton and Wolfgang Schrage. Special mention should go to the regular articles in the Tyndale Bulletin, particularly David W. J. Gill, 'The importance of Roman portraiture for head-coverings in 1 Corinthians 11:2-16', TynBul 41 (1990): 245-60; 'The meat market at Corinth (1 Corinthians 10:25)', TynBul 43.2 (1992): 389-93; Dirk Jongkind, 'Corinth in the first century AD: the search for another class', TynBul 52.1 (2001): 139-48; G. W. Peterman, 'Marriage and sexual fidelity in the papyri, Plutarch and Paul', TynBul 50.2 (1999): 163-72; David Instone-Brewer, '1 Corinthians 7 in the light of the GraecoRoman marriage and divorce papyri', TynBul 52.1 (2001): 101-15; '1 Corinthians 7 in the light of the Jewish Greek and Aramaic marriage and divorce papyri', TynBul 52.2 (2001): 225-43. 
support stemmed from his unwillingness to be adopted by a patron on the make for a famous apostle as a client. ${ }^{12}$

\section{b. Paul 'theologises' problems that the Corinthians do not necessarily view as theological}

We may go one step further: it is not evident from the text that there was consciously doctrinal factionalism in Corinth. Paul takes issue with the partisans of 1:12, not for any peculiar doctrinal slant, but because of the partisanship itself. He resolves the problem by showing all partisans in chapters $1-4$ that they misunderstand the newly revealed (and by its very nature, unifying) cross-gospel. He thus theologises something that they did not understand to be a doctrinal issue. ${ }^{13}$

\section{c. Were tongues a quest of the social elite?}

What if 'social climbing' is the key to their pseudo-philosophising, their disdain of conventional morality, and their banquets? Some scholars wonder if a display of tongues was also part of this same bag of tricks to accrue status. In this reading, the ultracharismatics would tend to have come from the 'haves' of the church. John K. Chow states that 'speaking in tongues could have been used by the powerful to denigrate the less spiritual people in the church'. ${ }^{14}$ Richard A. Horsley ('Spiritual elitism') wishes to pin the blame on Apollos for introducing Philonic thought into Corinth, making their elitism, denial of the resurrection, and the pursuit of prophecy and tongues a product of Sophia devotion. Dale B. Martin ${ }^{15}$ goes to the greatest lengths by arguing that tongues were already an accepted status symbol for society's powerful, in or out of the Christian church. He writes that 'in the absence of the critical perspective provided by modern "rationality" glossolalia in Greco-Roman culture - like esoteric speech in other

12 See the summary of patronage by Janet M. Everts, 'Financial support' in Dictionary of Paul and his letters (Downers Grove, IL: IVP, 1993): 295-300.

13 Some other examples of this 'theologising of the social' may be found in 1 Cor. 11:17-34; Phil. 4:2 within the context of the letter; 2 Thess. 3:6-12; Jas. 2:1-26; 3 John 9-11. We do not even begin to catalogue the examples in the gospels, Acts and Revelation.

14 John K. Chow, Patronage and power: a study of social networks in Corinth (JSNTSS, 75; Sheffield: Sheffield Academic, 1992): 184-85.

15 Dale B. Martin, The Corinthian body (New Haven, CT: Yale University, 1995): 8892; but especially his article, 'Tongues of angels and other status indicators', JAAR 59 (1991): 547-89. Along this line see too Roy A. Harrisville, 'Speaking in tongues: a lexicographical study', CBQ 38 (1976): 35-48; David E. Garland, 1 Corinthians (BEC; Grand Rapids, MI: Baker, 2003): 586. 
premodern cultures - would generally have been perceived as connoting high status' ('Tongues': 558). It 'seems almost always to be the property of leaders within groups' (561). Thus, Martin moves away from the modern assumption that tongues are associated with the lower class, to some debatable data that they may have been acceptable within the elite, and then to the conclusion that tongues were a status indicator. However, this is precipitously a priori reasoning that turns out to be ill-supported by the data. The single conceivable Jewish parallel occurs in Testament of Job 48-50, where Job's daughters speak in angelic tongues. The Greco-Roman parallels suggest an altogether different interpretation.

Faced with such meagre data, some scholars, particularly Martin, collapse glossolalia and prophecy into the single category of ecstatic speech. That is, if prophecy gave status, then tongues produced the same status. But as Christopher Forbes makes clear in his meticulous study Prophecy and inspired speech in early Christianity and its Hellenistic environment (released the same year as Martin's The Corinthian Body, 1995), the sign of spirituality, especially in Judaism, was prophecy, and not glossolalia; in fact, glossolalia was almost certainly not a known category. ${ }^{16}$ This harmonises with Paul's analysis in 1 Corinthians 12 and 14 where he clearly distinguishes between the two charismata.

\section{d. Did tongues convey an apostolic aura?}

Again, we turn to Chrysostom for insight: he traces the fascination with glossolalia not to Judaism or Greco-Roman society but rather to apostolic precedent. Since it was the original Pentecostal charism, and was practiced by Paul himself (as the Corinthians were well aware, 14:18), then tongues anoint one as more authentically apostolic. ${ }^{17}$ This turns up two centuries earlier in Irenaeus (Haer. 5:6:1):

16 Forbes: 262-63. See especially, Philo, Giants 61: Philo allegorizes Gen. 6:4 to mean that there are three types of human: those born of the earth (the carnal), those born of heaven (the intellectuals), and those born of God (priests and prophets). The prophets are not ecstatics, but intellectuals who have fixed their minds on incorporeal ideas. In this Philo is echoed by Origen, Cels. 7.4-7, who contrasts the true prophet with the Pythian - the true prophet is learned, the Pythian 'unlettered'; the prophet is a righteous man, the Pythian a sinful woman; when illuminated, the prophet receives a clear mind (7.4), the Pythian, a clouded mind.

17 Chrysostom, Hom. 1 Cor. 29.5, brings up the Corinthian view in order to refute it, 'Now it was supposed that this gift [of tongues] was a great one: in the first place because the apostles received it, and also because many Corinthians obtained it. But such is not the teaching of the Word'. Unless otherwise noted, we will use the ANF 
For this reason does the apostle declare, 'We speak wisdom among them that are perfect', terming those persons 'perfect' who have received the Spirit of God, and who through the Spirit of God do speak in all languages, as Paul used himself ${ }^{18}$ also to speak.

This passage is cited by Martin (Corinthian Body: 90-91), who draws the conclusion that tongues were associated with the elite of GrecoRoman society. But this is absolutely unconnected with Irenaeus' point, which is to show that spirituality has to do with possessing the Spirit, not in denying the fleshly body.

If the apostle has earlier urged the power elite to seek true wisdom from the Spirit, not from philosophy, then who better than ultracharismatics to plumb the divine mysteries (cf. the use of musterrion in 2:1 $\mathrm{NA}^{27}, 2: 7$ and 4:1 with 13:2 and 14:2)? The ultracharismatics might seek status in what they perceived to be an apostolic, not a societal, value.

\section{e. Did tongues allow some members to retreat into themselves in the cultus?}

Paul underscores that while the ultracharismatics were being built up as individuals, this could not be the purpose of any charism. By definition the church is corporate (12:19), and no one body part can function alone in God's administration.

and NPNF translation; the NPNF translation being garbled in this passage, we offer our own translation. Our view of Chrysostom is supported by Forbes: 12; Hurd: 281; Wayne A. Meeks, The first urban Christians: the social world of the Apostle Paul (New Haven, CT: Yale University, 1984): 119, '[One] means of gaining and using prestige and influence' was 'by behavior that the Pauline Christians recognized as directly manifesting the Spirit of God'; also Margaret M. Mitchell, The heavenly trumpet: John Chrysostom and the art of Pauline interpretation (HUT, 40; Louisville, KY: Westminster John Knox, 2002): 295 n. 451. For the sake of completeness, we must mention in passing the proposal of Antoinette C. Wire, The Corinthian women prophets: a reconstruction through Paul's rhetoric (Minneapolis, MN: Fortress, 1990), through their greater participation in worship the women were gaining status, provoking Paul to restrict their freedom.

18 We have amended with the italicized words the ANF translation, which apparently regards the last clause as a reference to the Spirit: 'as he used Himself also to speak'. The section is extant only in Latin (PG 7.1137), 'Propter quod et Apostolus ait: "Sapientiam loquimur inter perfectos;" perfectos dicens eos qui perceperunt Spiritum Dei, et omnibus linguis loquuntur per Spiritum Dei, quemadmodum et ipse loquebatur'. That Paul is the subject is equally allowed by the Latin and better suited to the context. The early church made much of Paul's charism of tongues; see John Chrysostom, In principium Actorum apostolorum 3.4 [PG 51.93; this is not the same as his better-known sermon series Homiliae in Acta apostolorum, PG 60], who argues that Paul spoke not with one charismatic tongue, but with many: 'tongues more than you all' (1 Cor. 14:18) taken as 'more tongues than you all'. 
The main sin of some Corinthians was acting in the cultus as if 'I have no need of you' $(12: 21)$ and 'I am not responsible for your edification' (cf. 12:7, 14:3-6, 12, 17-19, 26, 31). They may not have declared this aloud or developed it theologically; but de facto they worshipped as if they could interact with God (14:2) apart from interacting with the body - and their feeling of personal psychological exhilaration only confirmed their instincts. The apostle sees their reliance on tongues for status as boastful in 12:15-21, but it would be typically Pauline if this were his own analysis of what their selfsufficiency meant rather than a literal reporting of what they were actually doing. ${ }^{19}$ We may, however, legitimately apply the category of 'status' to this phenomenon - the ultracharismatics knew themselves to be independent agents while other Christians were not, and their resulting speech was loud and confusing.

Let us look back from the twentieth and twentiy-first centuries to see who might have been attracted to glossolalia in Corinth.

\section{Proposal from the Perspective of Latin American Pentecostalism}

\subsection{Class friction is one factor in the Corinthians' problems}

Once we cast doubt on the theory that glossolalia's appeal was for the upwardly mobile or elite class, another possibility suggests itself, one that has had strong echoes in Latin American Christianity (not to mention in other global Christian subcultures) since the second half of the twentiethth century. That is, that the ultracharismatic wave in Corinth was a by-product of the gap between rich and poor, between strong and weak, between the informed and the superstitious hoi polloi.

It is probable that there existed socio-economic tension in Corinth, as is shown in 1 Corinthians $11: 17-34 .^{20}$ Paul has heard about what is

19 Thus we are not persuaded by the orientation of Theodoret of Cyr, cited in G. Bray, ed., Ancient Christian Commentary on Scripture, VII: 1-2 Corinthians (Downers Grove, IL: IVP, 1999): 117, 'they did not use the gifts as they should have done. They were more interested in showing off than in using them for the edification of the church'.

20 We must acknowledge the fresh viewpoint of Justin Meggitt, Paul, poverty, and survival (SNTW; Edinburgh: T\&T Clark, 1998), that there were very few middle- or upper-class Christians in the Pauline churches. He argues that Paul's statements 'Do you not have homes to eat and drink in?' (1 Cor. 11:22) and 'If you are hungry, eat at 
going on prior to the Lord's Supper; he speaks to the elite, but on behalf of the disenfranchised of the church, represented perhaps by 'Chloe's people'. In a landmark work, Gerd Theissen forcibly argued that 'the conflict over the Lord's Supper is a conflict between poor and rich Christians' (151). Corinthians with pretensions to society were holding private dinners before the Christian meeting in order to impress their powerful friends; later in the afternoon, 'the Lord's Supper, instead of providing a basis for the unity of the body of Christ, is in danger of becoming the occasion for demonstrating social differences (160)' ${ }^{21}$ The other believers were made to wait outside while the elite enjoyed a leisurely dinner in the triclinium and received the flattery of inclusion. ${ }^{22}$ In another age, Prince Hamlet would joke about that same old axiom: 'Why should the poor be flatter'd?' (Hamlet, Act III, scene 2). For his part, Paul theologises their dining pattern and shows that the

home' (11:34) do not demand that his addressees own their own lavish peristyle homes. This may be so, but we counter that Paul's references to people such as Phoebe, Philemon, and Aquila and Priscilla necessitated that at least some of the disciples possessed property. See, too, the interaction with Meggitt by Dale B. Martin, 'Review Essay: Justin J. Meggitt, Paul, Poverty and Survival', JSNT 24 (2001): 51-64; Gerd Theissen, 'The social structure of Pauline communities: some critical remarks on J. J. Meggitt, Paul, Poverty and Survival', JSNT 24 (2001): 65-84; David L. Balch, 'Rich Pompeiian houses, shops for rent, and the huge apartment building in Herculaneum as typical spaces for Pauline house churches', JSNT 27.1 (2004): 27-46.

21 This from the essay 'Social integration and sacramental activity: an analysis of 1 Cor. 11:17-34', ch. 4 in Gerd Theissen, The social setting of Pauline Christianity. See too his "The strong and the weak in Corinth: a sociological analysis of a theological quarrel', ch. 3 in the same volume. Meggitt's case (190) is weak here, that the eating is of the sacrament itself: 'The community treated the elements of the Lord's Supper (v. 20) as though they were constituents of a normal meal (v. 21) with the consequence that when the church came together to eat (vv. 20,33) some consumed all the bread and wine quickly (v. 33), leaving others, who were less fast on the uptake, with nothing (v. 22).' Meggitt has to concede that the gorging of food and the drunkenness with which Paul charges them is grossly hyperbolic. He argues that unless this was a love feast gone to extremes, then the only explanation is that it is the sacrament itself.

22 Theissen ('The strong and the weak in Corinth': 125-29) has also reminded us that the poor of Corinth would have eaten meat only rarely, and perhaps only in conjunction with pagan feast-days. That hints that the strong who eat meat without scrupling in chs. 8-10 overlap with those who give feasts in ch. 11, where meat, fowl and fish delicacies would be served. This approach may likewise help us understand the weak brothers: they were outside the loop of the educated and did not share the 'knowledge' that the demons infecting the meat wouldn't harm them. This has neat parallels in Latin American Pentecostalism, which tends to foster a Manichean dualism between God and the demonic. See Juan Sepúlveda, 'Pentecostal theology in the context of the struggle for life' in D. Kirkpatrick, ed., Faith born in the struggle for life (Grand Rapids, MI: Eerdmans, 1988): 298-318, who attributes this dualism to 'a real experience of the negativity and brutality of the world'. 
gospel must be applied even to dinner parties. With prophetic insight he links the high death rate in the church with the shaming of the havenots.

\subsection{Class divisions may explain the existence of an ultracharismatic group}

It is a feature of the Latin American church that Pentecostal fervour may be correlated with low social and economic status. When in the mid-20th century it became a grass-roots movement rather than an import from the North, Pentecostalism exploded among the poor. ${ }^{23}$ Among other blessings it gave them the sense of identity that they badly lacked. Juan Sepúlveda writes of the Brazilian church that whereas in society and in church they were marginalised, 'in pentecostalism every believer is a direct and legitimate producer of his or her religious world. They thus defy not only the traditional way of doing religion, but the very structure of a classist society', though in non-political ways. ${ }^{24}$

Bryan Wilson in his paradigmatic study Magic and the Millennium describes some American (and other) tribal sects as 'isolationist', that is, leading to 'the establishment of a separated community preoccupied with its own holiness and its means of insulation from the wider society'. ${ }^{25}$ We must not take this too far, since Pentecostals congregate with like-minded Christians and form churches, denominations and quasi-denominations. Yet Wilson does provide us with a legitimate half of the picture: 'In adopting the denominational model of the Protestant missions, the thaumaturgical movements have transformed the Protestant demand for "every man a priest" to "every man a thaumaturge" ... [however] the individual's charisma must be validated in a charismatic community, in which the gifts are manifested in some sense for the corporate benefit' (170). We must add to this the other

23 This is the same observation that Celsus made, albeit sarcastically, against Christians in general in the mid-second century, that its supposed nonsensicality made it appealing only to the uneducated classes. See Origen, Cels. 3.44 ; 7.4-7 and the careful analysis of Celsus' view by Thomas W. Gillespie, 'A pattern of prophetic speech in First Corinthians', JBL 97/1 (1978): 74-95.

24 Juan Sepúlveda, 'Religion and poverty in Brazil: a comparison of Catholic and Pentecostal communities' in G. Cook, ed., New face of the Church in Latin America: between tradition and change (Maryknoll, NY: Orbis, 1994): 72.

25 Bryan R. Wilson, Magic and the millennium: a sociological study of religious movements of protest among tribal and third-world peoples (New York: Harper \& Row, 1973): 24. 
truth that, within such communities, individuals might practice their charismata in isolation one from the other.

In Latin America, socio-economic class is only relatively static: conversion to the gospel, for example, has provable benefits for the marginalised. These come almost immediately when there is freedom from alcohol abuse and family disintegration and the introduction of a new work ethic. In the next generation there may be university education and rising social status. This can lead to a shift, not only in status, but also in theology, as extreme Pentecostalism appears less and less relevant to second- and third-generation believers. ${ }^{26}$

Besides upward mobility for Christians, there is an intramural rearrangement of status. After decades of growth, Latin American Pentecostalism has developed its own hierarchy, often at odds with prior status arrangements. ${ }^{27}$ But here we must remember that Corinth is far from this situation. The ultracharismatics of Corinth are redefining

26 José Míguel Bonino, 'The Pentecostal face of Latin American Protestantism' in Faces of Latin American Protestantism, tr. E. L. Stockwell (Grand Rapids, MI: Eerdmans, 1997): 69, states that 'it may be that many Pentecostals are poor or marginalized, but as a whole they represent now a social and political force'. He wonders whether Pentecostalism is now 'threatened by the same social factors that made its development possible'. See, too, Manuel J. Gaxiola, 'The Pentecostal Ministry', International Review of Missions 66 (1977): 57. For a useful overview of what happens when the formerly-marginalized become part of the elite, see W. J. Hollenweger, 'The Pentecostal elites and the Pentecostal poor: a missed dialogue?' ch. 9 in Karla Poewe, ed., Charismatic Christianity as a global culture, (Columbia, SC: University of South Carolina, 1994); Paul Freston, 'Charismatic Evangelicals in Latin America: mission and politics on the frontiers of Protestant growth' in S. Hunt, M. Hamilton and T. Walter, eds., Charismatic Christianity: sociological perspectives (Basingstoke: MacMillan, 1997), who charts the growth of middle-class Pentecostalism.

27 André Droogers, Algo más que opio (San José, CR: DEI, 1991; also available in English as More than Opium, Lanham, MD: Rowman \& Littlefield): 26; R. Andrew Chesnut, Born again in Brazil: The Pentecostal Boom and the Pathogens of Poverty (New Brunswick, NJ: Rutgers, 1997), esp. ch. 6: 'Authoritarian assembly: Church organization'. Chesnut shows how a Pentecostal church (in this case, the Assembly of God in Brazil) may move toward a highly authoritarian leadership structure. Those who obey the head receive favours, and those who do not fail to advance. 'In reality, the head of the church decides on important matters behind closed doors with a cabal of pastors'. (130) This has a historical parallel in Montanism. If Tertullian (Jejun. 11) touts a more democratic version of Christianity with his '[we] are all priests of one only God the Creator and of His Christ', then his movement was swiftly moving toward a hierarchy as rigid as any: see William Tabbernee, 'Montanist regional bishops: new evidence from ancient inscriptions', JECS 1 (1993): 249-80. To take one example: although Montanism and some contemporary Pentecostals formally advocate a place for charismatic females in the leadership structure, with ongoing organization they may once more leave women and other marginalized groups on the sidelines. 
status but have no opportunity - perhaps no desire - to seize power. We will be wary of referring to their activity as direct subversion. Their aim is to affirm to themselves and to others, their own value, thereby undermining the values of the higher class through a mystical inside track with God. ${ }^{28}$

In Corinth, the poor and disconnected stood no chance of impressing others with books and hired philosophers and clever banquet conversation. Instead, these Christians would excel in areas where worldly status did not matter, in fact, was an impediment: they were 'speaking not to human beings but to God' and 'uttering mysteries in the Spirit' (14:2). Within the cultus, the ultracharismatic not only experienced direct contact with God, but also was released from dependence upon his or her 'betters' for teaching and administration.

\subsection{Corinthians 11 and 12-14 as two sides of one issue}

The peri de in 12:1 ('now concerning') makes it likely that the Corinthians had asked about the pneumatika. ${ }^{29}$ Despite the absence of peri de in 11:2-16, it is likely that the Corinthians had also written about veils for women. 1 Corinthians 11:17-34 deals with the Lord's Supper: had the Corinthians questioned Paul about it, which the apostle also does not bother to mark with peri de? In this case, no. It was more likely that his information had arrived unofficially, from the alienated. No-one was abusing the rite itself (contra Conzelmann: 14; Meggitt: 190), but a crime does comes to light if one examines it, as Paul does, in connection with the feast given beforehand (so Lietzmann; Thiselton; Garland). Thus, he interrupts his responses to the official questions and responds to the unauthorised one:

- The Corinthians had written: Concerning meetings of the church (no peri de) - How serious were you when you said that women had to wear veils in the meeting?

- Paul answers that he had been quite serious, 11:2-16.

- Paul then interjects, drawing from other sources of information from Corinth (again, no peri de) - And by the way, while we're speaking

\footnotetext{
28 Wayne Meeks (120) speculates that there were two 'different modes of power' at work in Corinth. Thus, 'conflict between possessed behavior [glossolalia] and more structured forms of power would not be surprising'.

29 Contra Margaret M. Mitchell, 'Concerning PERI DE in 1 Corinthians', NovT 31, 3 (1989): 229-56.
} 
about your meetings: don't you know that the Lord's Supper should show the church at its most unified in love, 11:17-34?

- The Corinthians had written: Concerning (peri de) the spiritual gifts - Is it really true that this new manner of speaking in tongues is a sign of spiritual depth, 12:1-14:39?

In other words, the apostle himself chose 11:17 as the location for his teaching on the Lord's Supper. Yet readers may well wonder why this section does not follow immediately on chapter 10 which, after all, had had to do with sacramental meals, the unity of the body of Christ, the principle of surrendering one's exousia to build up ones fellow Christian, and the crime of giving offence to the church of God (10:32). Remove 11:2-16 and with some minor smoothing the text would flow very well.

It could be that 11:17-34 is here simply to provide balance for the epideictic 'I praise you in X, I do not praise you in Y' formula. But we propose instead that section is intentionally placed here, and that there is a stronger connection between 11:17-34 and chapters 12-14 than is obvious from the surface. The section ends with the elite and the marginalised eating apart. It is at this point Paul turns to their question about spiritual gifts. He goes into a long discussion where, once again, he touches on the unity of the body and the supreme value of love. He finally makes plain in chapter 14 what is in hindsight hinted at in $12: 28-31$, that it is the charism of glossolalia that some had been misusing.

Is it possible that 12:1 follows 11:34 because they are two sides of one and the same issue, that is, flaws in the assembly that follow from class tension at Corinth? On the one hand, an elitist group divided the church with its exclusive dinner invitations, a minor social convention that would have gone unquestioned by most. Yet Paul sees it by extension as a violation of the Lord's Supper and punishable by sickness or even death (11:30). On the other hand, some were overusing tongues in the assembly and withdrawing into themselves. Although they, too, were in error, the ultracharismatics at least shared Paul's appreciation of the centrality of the Spirit. The apostle merely channels their energy toward a higher value, that the true person of the Spirit uses his/her charism for others. They erred only in being 'childish' (14:20; cp. this with the stiffer language in $3: 17,4: 8,4: 21$; or 
11:18-19, which I take to be ironic and addressed to the elistists), ${ }^{30}$ but no one would be struck dead for using glossolalia too much.

\subsection{Abuse of tongues was an 'anti-status status symbol' and means of withdrawal}

The factions in 1:12 were fighting each other for status. At the same time, tongues came to be a symbol - better, an anti-status symbol - a reaction against the ongoing status contest. These ultracharismatics were perhaps not partisans of any of the spokesmen of 1:12; they were excluded or withdrew from that competition, and perhaps found it disgustingly opposed to the gospel they had been taught.

Is it plausible, as we will now ask, that while the whole epistle is directed to the entire church, certain portions are for particular individuals or groups? Naturally, any such theory must be tentative: one might think, for example, of the notion that the two Thessalonian letters were written, one to Jews and one to gentiles. Yet in 1 Corinthians especially, there are strong internal indicators that Paul is addressing now one, now another group. First, he points out that some Corinthians were following the Greek error of seeking 'wisdom' (1:22); presumably others were not, but all Corinthians will hear chapters 1-4. Some built wisely on the apostolic foundation of the church, but all 'construction workers' will listen to the warning to the reckless builders in 3:10-15. One person sued a brother, but now everyone will have to sit through the lecture $(6: 1-8)$. Some went to prostitutes, but all will be warned (6:15-20). The whole church hears in chapter 7 teachings given to people of specific civil status; the 'knowledgeable', the weak, and those in-between - all attend to all the teaching of chapters 8-10. In chapter 14 , he speaks now to women, now to the whole church; he mainly corrects those who abused tongues, but also to those who might abuse prophecy, or (ch. 12) any charism. Later, 'some of you say there is no resurrection of the dead', but all of them will hear the proofs for the apostolic doctrine. Thus there is precedent for a hypothesis that a sub-group addressed in one section of the letter is not identical to one addressed elsewhere.

1:10-4:21 and 11:17-34 reproach the upwardly mobile. But in chapters 12-14 Paul points out that others, too, are trying to compete, albeit in a backhanded way. It was only in the church meeting that they

30 As does Richard A. Horsley, 1 Corinthians (Nashville: Abingdon, 1998): 159. 
could break out and be special: no one could forbid them from being either self-focused or the noisy centre of attention, as this was the Spirit's work; and at last it would be the elitist, the one least likely to want to look odd or foolish, who would feel like a 'foreigner' (barbaros, 14:11). Paul, for his part, throws all members of the church into that reprehensible social category - for whether a member is gifted with tongues or not, all members are hearing other members speaking strange languages; ironically, even the ultracharismatics are at some level being alienated by the charism. But in the end, we must modify the thought of Thiselton, who says that "the "gifted" seem hardly to care if less "gifted" believers somehow feel estranged or secondclass'. ${ }^{31}$ This is to read it backwards: rather, the gifted were misusing their gifts because they had already been made to feel second-class, not least in being held off from the triclinium.

There are parallels of this throughout church history, although our examples have to do with prophecy rather than glossolalia:

1. Status and hierarchy: Montanus provides some useful comparisons to the Corinthians. He was regarded as evil, partly because he bypassed the church hierarchy of Phrygia, continued prophesying after being excommunicated and relied on his prophetic gift and magnetic personality to command his followers. ${ }^{32}$ There also existed a tradition that he was a recent convert (Eusebius, Hist. eccl. 5:16) and that had been a pagan priest before his conversion (Didymus Caecus, Trin. 3:41). His charismatic gifts probably helped him to make the lateral leap from priest to prophet without a loss of status.

2. Urban status: Since Montanism was a primarily rural movement, it suffered from the prejudice of city-dwellers. Besides, it did not fit easily within the orbit of church hierarchy, whose bishops were situated in cities. ${ }^{33}$

3. Status and gender: Irenaeus was no enemy of charismatic utterance by men or women (Haer. 3:11:9; see also Justin Martyr, Dial. 87-88). Still, he was entirely willing to shelve his egalitarianism when

31 Thiselton, 1 Corinthians: 799.

32 Martin, Corinthian Body: 89, uses Montanus to prove that glossolalia bestowed higher status in the movement, and that lower-status Montanists were such because they lacked the gift. We respond that glossolalia was not part of a uniquely Montanist experience, and that any assumption about what charismata the lower-class Montanists possessed is pure speculation.

33 See D. H. Williams, 'The Origins of the Montanist Movement: A Sociological Analysis', Religion 19 (1989): 331-51. 
his opponents found support among women, whom he thought gullible and emotionalistic. In 1:13:1-3 he complains of a certain Marcus, who 'devotes himself especially to women'; he gets a woman to prophesy by playing on her emotions, 'her heart beating violently'. The polemicists Hippolytus (3rd century) and Epiphanius (4th) also objected to women charismatics ... but again, only when they prophesied for the opposition. ${ }^{34}$

Thus new converts, rustics, women, and the generally disenfranchised found new status and self-affirmation by side-stepping the ecclesiastical structure and engaging in untraditional, marginal charismatic activity. Likewise, the ultracharismatics in Corinth were rebuffing the Roman system of status that had fascinated some of the church. So what if the arrivistes in Corinth valued the ability to teach with rhetorical skill? The poor could retreat into glossolalia, worshipping God in the Spirit and at the same time hiding their lack of sophistication behind the cloak of indecipherable speech.

\subsection{Paul's response concerning the charismata}

Paul's rebuttal runs as follows:

1. Yes, glossolalia is a true charism. Yet, isolationist and untranslated glossolalia in no way builds up the church; in some ways it harms it.

2. The aim of any charism is to build up the church, not the gifted individual. Anyone who is spiritual will also - primarily - excel in agape and thus have edification as his/her goal. Besides, individual prayer can be done at another time and place.

3. Therefore: speakers in tongues should pray for an additional charism, for example interpretation or prophecy.

This all clarifies how key is the paean to Christian love in the middle of this three-chapter complex. ${ }^{35}$ Rhetorically, Paul steps back and dictates an egressio, a generalizing exhortation. He shows in chapter 13 as he did in 8:1-3 that their root problem is a lack of agapē.

34 Cf. Hippolytus, Haer. 7.26; 8.12; Epiphanius, Pan. 49. See Gary S. Shogren, 'Christian Prophecy and Canon in the Second Century: A response to B. B. Warfield', JETS 40/4 (Dec. 1997): 609-26. See also Christine Trevett, Montanism - Gender, Authority and the New Prophecy (Cambridge: CUP, 1996) who, in my opinion, leaves insufficiently explored some of the fascinating gender issues hinted at in the title.

35 See James Patrick, 'Insights from Cicero on Paul's reasoning in 1 Corinthians 1214: love sandwich or five course meal?’ TynBul 55.1 (2004): 43-64. 
There are pastoral implications to Paul's method in the epistle. He strips the elitists of their worldly baubles; but he also takes from the marginalised their sole status chip, which likewise is distracting them from true service. For the sake of Christian love, they are told to cease 'stepping out' of the body of Christ into an individualistic experience. Their glossolalia is community property, and must be translated for all; or they are to prophesy and to submit their message to the discernment of the others; or perhaps they are to teach, but be limited to their rude, unmannered style - but all this and more is possible with the Spirit's power. ${ }^{36}$ The gospel's solution is not retreat, nor flight, nor subversion, nor acquiescence to the existing order established by the 'strong', but intentional, voluntary, spiritual service in agape .

\section{Conclusion}

The ultracharismatics were drawn from the socially disaffected of the Corinthian church. They latched on to glossolalia as a means of turning inward to God but away from Christ's body, especially during meetings. In so doing they snubbed the values of their social 'betters' by emphasizing their connection with God's Spirit and their disconnection from the foolishness of worldly wisdom, flattery and status.

Latin America has had decades of development from a similar starting point. Today one may point to other features that have grown out from that matrix:

- The rejection of 'worldly' values may take the form of antiintellectualism. While on the one hand many Christians value education or see it as a divine blessing, others view it dualistically as a tool of evil. They contrast the charismatic power of Pentecostalism with the supposed sterility of groups that (also) value intellect. ${ }^{37}$

- Battles regularly break out between Pentecostal individuals, leaders and groups, about who is more charismatically endowed.

- Charismatic leadership by women or the chronically poor, while formally affirmed, is in practice discouraged by an emerging

36 So Calvin's commentary on 1 Cor. 14:1.

37 Concerning the challenge of theological education within the anti-education milieu of Pentecostal Chile, see Juan Sepúlveda, 'El desafío de la educación teológica desde una perspectiva Pentecostal', Ministerial Formation 87 (Oct. 1999): 35-41. 
hierarchical structure. In the case of poverty, it may be tacitly assumed that a true person of the Spirit would have left poverty behind.

- Material prosperity is reinterpreted not as a sign of worldly class status (elitism) but as a sign of spiritual status (unusual faith that leads to prosperity).

Perhaps we see in Latin America what a Pauline church might have looked like had the ultracharismatics not gone unchecked. But let us be wary of reading a developed situation into a Corinthian church that had had only a handful of years to evolve. 